\title{
Where does Russia head now?
}

Against some odds, President Boris Yeltsin has won the part of the Russian referendum that he says matters most, but the really hard work is only just beginning.

Mr Boris Yeltsin, the president of Russia, may have won the battle, but he has not yet won the war he has been fighting for more than half a year with the Congress of People's Deputies. That is how it seemed earlier this week, as people began making educated guesses about the outcome of the weekend's referendum. It seems certain that Yeltsin will have won the trust of a handsome majority of those turning out to vote; consistently, he has said that this is the only question he would take seriously. On the other hand, he is likely to have failed to win a majority of the whole electorate for an early reelection of the Congress. That is bad news, and threatens a continuation of the debilitating battle between the government and the parliament that has dragged on since last November.

Perpetuation of the pantomime of the past few months will serve nobody's purpose. It is true, of course, that for the first time in 75 years, Russia now has in place the mechanisms of national democracy - a government whose president has been elected and a parliament able to enforce, by argument and voting, restraints on what the government does, as well as a constitutional court. But the Congress in its present form dates back to Mikhail Gorbachev's; it was not elected by general suffrage, but (on behalf of the whole of what was still the Soviet Union) partly elected on a local basis and partly nominated by special interest groups. (The All-Union association of philatelists had a separate influence, for example.) The old Central Committee's placemen are still there. No wonder that the government and the Congress have been at loggerheads.

Some of the consequences have been absurd. Early on, the Congress won the right to control Russia's central bank, which has since kept on printing money with which to subsidize bankrupt enterprises, thereby undermining Yeltsin's efforts to engineer economic reform. During the same period, it has voted to change the Russian constitution - itself new - on roughly 50 occasions. Who can be surprised that ordinary people do not know where they stand? And while irrational resentment abounds in Russia (and in the Congress) about the way in which economic reform has created several battalions of dollar-millionaires, many of Yeltsin's problems stem from the sharp practices that have allowed these small fortune to accumulate, mostly unhindered by taxation.

So what should Yeltsin now do? Forbidding though the prospect may be, he needs another talking shop - a commission whose function would be to draw up a definitive Russian constitution that could then be entrenched against the amending whims of the Congress. (Amendment only by referendum would make sense.) Legislating for seemly relationships between the government and the Congress may be the most urgent need; creating the circumstances in which the patchwork of titularly and hopefully autonomous regions that make up the Russian Federation have an incentive to hang together is, in the long run, more important. Yeltsin could do his country a power of good by directing public attention to these issues.

Can he succeed? There are two views of what has happened in Russia in the past few years. One is that it has lapsed into chaos. Another is that it has survived this far only because of a remarkable social cohesiveness (in which traditional fatalistic passivity may have played an important part). Both views embody aspects of the truth. On the whole, the durability of this remarkable society is the more impressive. Yeltsin has that on his side. But he must do more to suppress the air of lawlessness that now abounds (which would incidentally take wind out of the Congress's sails) and persuade people that paying taxes is a social virtue (which would then help balance Russia's books).

No part of Russia's social fabric is more durable than its network of people with research at heart. To be sure, many able people have now gone elsewhere. Others have been forced out by impoverishment. It is far from clear that the hope of the Russian Academy of Sciences that industrial contracts can keep the rump of its establishments in being can be realized; experience in other countries is not encouraging. Yet there remains a core of Russian research, not simply academic, that remains excellent and which seems certain to survive. Yeltsin could help by ridding it of bureaucratic incubuses. He will not in the long run profit from arrangements that turn the surviving research institutes into training grounds for emigrant specialists.

But would it matter all that much if Yeltsin failed? Russia, after all, is not the only member of the Commonwealth of Independent States. Do not the other eleven deserve at least as much attention, even compassion? And what of the states of Central Europe, themselves also recently unshackled? The answer should be, "Of course". There is indeed a serious danger that Western preoccupation with Russia's plight will induce neglect, even complacency, about the remainder of the ex-Soviet empire. Yet what happens in Russia is distinctively important. Its sheer size is one consideration, its huge stock of military equipment is another. And Yeltsin's failure would probably presage a revival of the old nationalism that drove the tsars to the Pacific coast of Asia. Who would benefit from that? 